\title{
Apresentado na I Jornada Científica do Esporte Coletivo Recife - PE, 2018. EVOLUÇÃO TÁTICA NO FUTEBOL MUNDIAL
}

\section{Professor Esp. Alexandre Julião.}

Os conceitos sobre Evolução, Tática, Sistema, Modelo de jogo, Amplitude, Compactação, Profundidade e outros, podem apresentar estes aos ouvintes pontos primordiais para discutirmos a Evolução Tática no Futebol Mundial. Apresentamos na I Jornada Científica do Esporte Coletivo, Recife - PE, como e onde surgiram os primeiros sistemas e táticas no futebol antes e após a regulamentação Dessa modalidade, demonstramos que os primeiros sistemas e táticas se preocupavam exclusivamente em colocar mais jogadores para atacar do que para defender, alguns treinadores começaram a iniciar uma revolução pensando trazer jogadores da linha de ataque para o meio campo e para a linha defensiva, sempre buscando um equilíbrio entre os setores; alguns destes sistemas eram fortalecidos se obtivessem sucesso nas Copas do Mundo ou em Ligas como a da Europa, alguns duraram anos como modelo para clubes e seleções. Por último, foram apresentados modelos e fotos de equipes e seleções no futebol mundial dos últimos dez anos até a presente data, provaram que nos centros mais avançados de estudos as equipes atuam com ideias bem definidas, bem organizadas taticamente, jogando compactadas, com amplitude e profundidade, algumas jogando com sistemas utilizados no passado, como o 1-3-5-2, 1-3-4-3 e até o 1-4-5-1, o que evoluiu mais foram as táticas do jogo. Palavras-chave: Futebol, Evolução, Tática, Modelo de Jogo.

Email: juliaoalex@hotmail.com 